Archive for

Organic Chemistry

Arkivoc 2020, part vii, 27-35

\title{
Synthesis of 4,5,6-trichloropyrimidine-2-carbonitrile from 4,6-dichloro-2-(methylthio)pyrimidine
}

\author{
Andreas S. Kalogirou ${ }^{a *}$ and Panayiotis A. Koutentis ${ }^{b}$ \\ ${ }^{a}$ Department of Life Sciences, School of Sciences, European University Cyprus, 6 Diogenis Str., \\ Engomi, P. O. Box 22006, 1516 Nicosia, Cyprus \\ ${ }^{b}$ Department of Chemistry, University of Cyprus, P. O. Box 20537, 1678 Nicosia, Cyprus \\ Email: A.Kalogirou@euc.ac.cy
}

\section{Dedicated to Professor Jan Bergman for his outstanding contributions to the field of organic chemistry}

Received 02-24-2020

Accepted 04-30-2020

Published on line 05-05-2020

\section{Abstract}

A route to 4,5,6-trichloropyrimidine-2-carbonitrile was developed starting from 4,6-dichloro-2-(methylthio)pyrimidine. The latter was converted to 4,6-bis(benzyloxy)-5-chloropyrimidine-2-carbonitrile in four steps giving an overall yield of $67 \%$. The steps involved nucleophilic displacement of the 4,6-chlorides by benzyloxide, followed by oxidation of the sulfide group to sulfone, its displacement by cyanide and chlorination at the pyrimidine C5 position with NCS. 4,6-Bis(benzyloxy)-5-chloropyrimidine-2-carbonitrile was finally converted into 4,5,6-trichloropyrimidine-2-carbonitrile in a moderate (30\%) yield in a two-step procedure.<smiles>CSc1nc(Cl)cc(Cl)n1</smiles>

Keywords: Pyrimidines, chlorination, cyanation, nucleophilic displacement 


\section{Introduction}

Pyrimidines are important aromatic $\mathrm{N}$-heterocycles that are widely found in nature, for example, as components of the pyrimidine nucleotides cytosine (C), thymine (T), and uracil (U) and vitamin B1 (thiamine). Not surprisingly, the chemistry of pyrimidines has been investigated for over a century and numerous reviews have appeared. ${ }^{1}$ Pyrimidines are also present in many drugs such as the CNS depressant phenobarbital, the anticancer drug fluorouracil and the antibacterial trimethoprim (Figure 1). Additional pharmaceutical applications include uses as diuretics, ${ }^{2}$ anti-inflammatory, ${ }^{3}$ anti-malarial, ${ }^{4}$ and anti-tumor agents. ${ }^{5}$

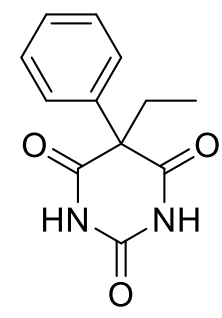

phenobarbital<smiles>O=c1cc(F)[nH]c(=O)[nH]1</smiles>

fluorouracil<smiles>COc1cc(Cc2cnc(N)nc2N)cc(OC)c1OC</smiles>

trimethoprim

Figure 1. Pyrimidine containing drugs.

Our interest in pyrimidines started with 4,5,6-trichloropyrimidine-2-carbonitrile (1), which was isolated two decades ago as an unexpected minor product (1-5\%) from the reaction of tetracyanoethene (TCNE) with $\mathrm{SCl}_{2}$ during the preparation of 2-(3,5-dichloro-4H-1,2,6-thiadiazin-4-ylidene)malononitrile (2) (Scheme 1). ${ }^{6}$ To date, our most efficient synthesis of pyrimidine $\mathbf{1}$ involves the highly reactive tetrachlorothiadiazine $\mathbf{3}$ which is converted first into perchloro-9-thia-1,5,8,10-tetraazaspiro[5.5]undeca-1,4,7,10-tetraene (4), and then degraded to the target pyrimidine in $53 \%$ overall yield (Scheme 1$)^{7}$

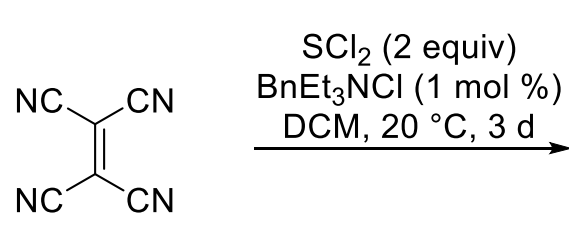<smiles>N#Cc1nc(Cl)c(Cl)c(Cl)n1</smiles>

$1(5 \%)$<smiles>ClC1=NC2(N=C(Cl)C1(Cl)Cl)C(Cl)=NSN=C2Cl</smiles>

$\mathrm{BnEt}_{3} \mathrm{NCl}(0.5$ equiv)

$\underset{81 \%}{\stackrel{\text { PhMe, ca. } 110{ }^{\circ} \mathrm{C}, 1 \mathrm{~d}}{\longrightarrow}} \mathbf{1}$

Scheme 1. Preparation of trichloropyrimidine-2-carbonitrile (1) from TCNE and from tetrachlorothiadiazine $\mathbf{3}^{6,7}$

4,5,6-Trichloropyrimidine-2-carbonitrile (1) is interesting due to its multiple reactive sites and potentially it offers rich chemistry via transition metal-catalysed coupling reactions or nucleophilic substitutions at the 
chlorine-substituted C4/6 carbons, as well as via modification of the C2 nitrile group. However, the chemistry of the trichloropyrimidine 1 has remained unexplored due to its low yielding synthesis. To date, the known chemistry of trichloropyrimidine $\mathbf{1}$ is limited only to the nucleophilic displacement of the C4 chloride by $\mathrm{DABCO}$ to give piperazine $\mathbf{5}^{8}$ and its involvement in the formation of the fused thiazole 6 from the degradation of tetrachlorothiadiazine 3 (Scheme 2). ${ }^{9}$<smiles>N#Cc1nc(Cl)c(Cl)c(Cl)n1</smiles><smiles>ClC1=NSN=C(Cl)C1(Cl)Cl</smiles>

3

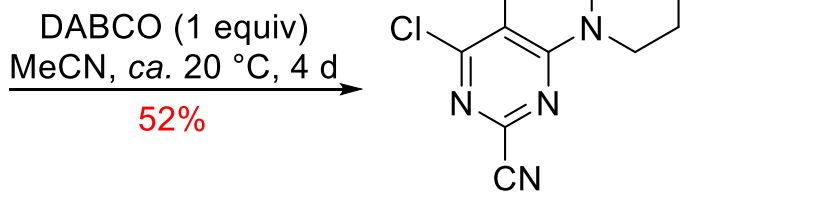

5

$$
\mathrm{BnEt}_{3} \mathrm{NCl}(10 \mathrm{~mol} \%)
$$

PhMe, ca. $110^{\circ} \mathrm{C}, 24 \mathrm{~h}$

Scheme 2. Reactions of 4,5,6-trichloropyrimidine-2-carbonitrile (1) and structure of 2,4,6-trichloropyrimidine5-carbonitrile (7).

Directly comparable is the isomeric 2,4,6-trichloropyrimidine-5-carbonitrile (7) (Scheme 2), which was prepared as far back as $1964,{ }^{10}$ and has since been extensively used as a precursor to dyes, ${ }^{10}$ herbicides, ${ }^{11}$ antithrombotics, ${ }^{12}$ and inhibitors of phosphoinositide 3-kinases (PI3Ks). ${ }^{13}$

To investigate the chemistry of trichloropyrimidine-2-carbonitrile (1) further, we required access to larger quantities, and pursued various independent syntheses. An alternative route to pyrimidine 1 to the ones described above started from the dichloropyrimidine $\mathbf{8}$ that was easily prepared from thiobarbituric acid. ${ }^{14}$ Dichloropyrimidine $\mathbf{8}$ was converted into the dimethoxypyrimidine $\mathbf{9}$ by nucleophilic displacement by methoxide (Scheme 3). Subsequently, oxidation of the thioether group and substitution by cyanide gave pyrimidine 11. The latter was chlorinated at the C5 position using NCS to give chloropyrimidine 12, but the subsequent hydrolysis of the methyl ethers failed, thereby halting the synthesis of trichloropyrimidine $1 .^{15}$

In light of the hurdles encountered during the above synthesis we chose the more labile benzyl ether protecting group that could be more readily deprotected to afford the dihydroxypyrimidine 13 . Herein, we report a successful synthesis of pyrimidine 1 starting from $\mathbf{8}$ in an overall yield of $20 \%$. 


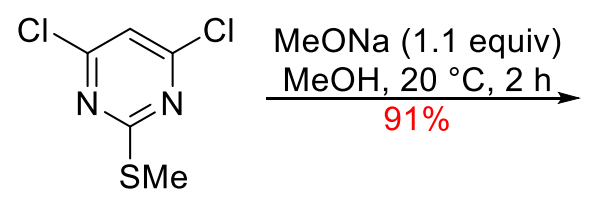

8<smiles>COc1cc(OC)nc(SC)n1</smiles>

9
MCPBA ( 2 equiv)
$\underset{\text { DCM, } 0{ }^{\circ} \mathrm{C}, 1 \mathrm{~h}}{ }$<smiles>COc1ccnc(S(=O)(=O)OC)n1</smiles>

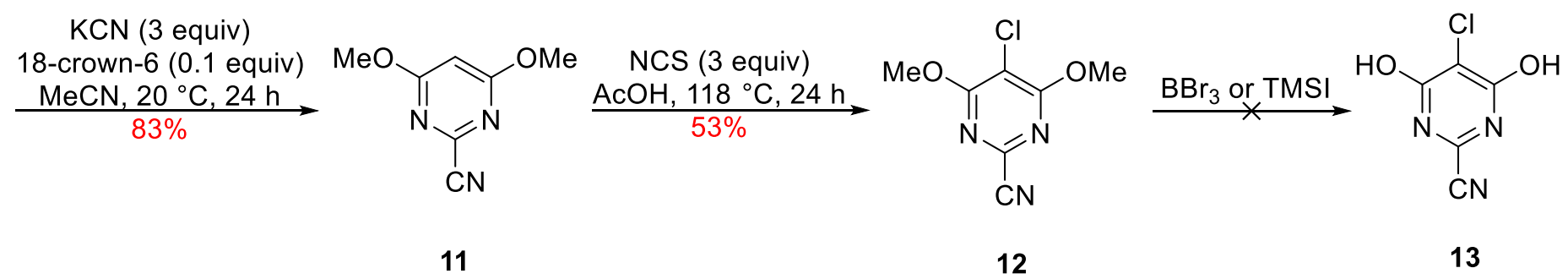

Scheme 3. Attempt to prepare trichloropyrimidine 1 from 4,6-dichloro-2-methylthiopyrimidine.

\section{Results and Discussion}

Our independent synthesis began from the known 4,6-dichloro-2-(methylthio)pyrimidine (8) that was prepared in two steps and $92 \%$ overall yield from thiobarbituric acid. ${ }^{14}$ Thiobarbituric acid is a valid starting material for this route due to its good availability, low cost and the high yield of its transformation to dichloropyrimidine $8{ }^{15}$ The displacement of the $\mathrm{C} 4$ and $\mathrm{C} 6$ chlorides by benzyloxy groups proceeded smoothly to give dibenzyloxypyrimidine 14 in $86 \%$ yield (Scheme 4). While dibenzyloxypyrimidine 14 has already been reported in the literature starting from 2,4,6-trichloropyrimidine, ${ }^{16}$ this new synthesis provides an alternative route from more readily available thiobarbituric acid.

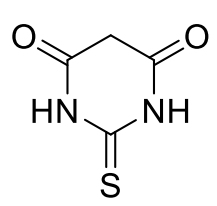

1) $\mathrm{Mel}(1.1 \mathrm{eq}), \mathrm{NaOH}(2 \mathrm{M})$

$\mathrm{EtOH}, 60^{\circ} \mathrm{C}, 2 \mathrm{~h}$

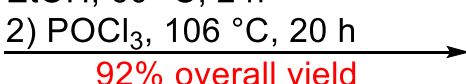<smiles>CSc1nc(Cl)cc(Cl)n1</smiles>

8

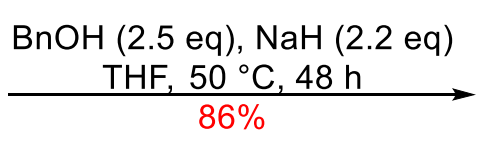

$\underset{86 \%}{\mathrm{THF}, 50{ }^{\circ} \mathrm{C}, 48 \mathrm{~h}}$<smiles>CSc1nc(OCc2ccccc2)cc(OCc2ccccc2)n1</smiles>

14

Scheme 4. Preparation of the dibenzyloxypyrimidine 14.

Subsequent oxidation of the thioether moiety in pyrimidine 14 was performed by MCPBA (2 equiv), in $\mathrm{DCM}$, at $\mathrm{ca} .0^{\circ} \mathrm{C}$, to give sulfone 15 in excellent (94\%) yield (Scheme 5). Displacement of the sulfone with cyanide was achieved using $\mathrm{KCN}$ in MeCN to afford the pyrimidine-2-carbonitrile 16 in $87 \%$ yield (Scheme 5). 


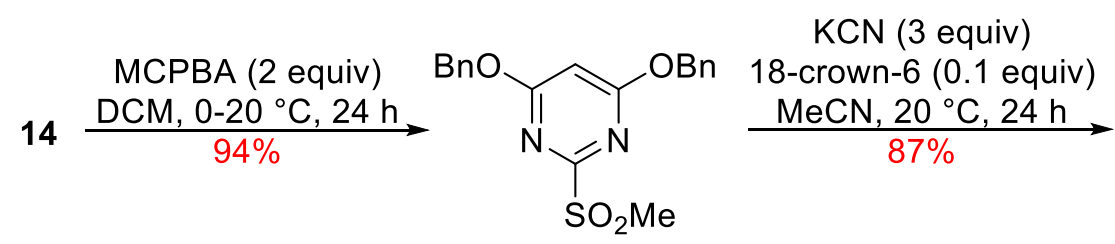

15<smiles>N#Cc1nc(OCc2ccccc2)cc(OCc2ccccc2)n1</smiles>

16

Scheme 5. Preparation of sulfone 15 and carbonitrile 16.

The chlorination of cyanopyrimidine 16 occurred upon treatment with NCS (3 equiv) in $\mathrm{AcOH}$, at $c a$. $118^{\circ} \mathrm{C}$, to give 5-chloropyrimidine 17 in an excellent (95\%) yield (Scheme 6). With 5-chloropyrimidine 17 in hand, we then investigated the deprotection of its benzyl ethers. Initially, we attempted the deprotection by hydrogenation using $\mathrm{H}_{2}$ (2.6 bar), $\mathrm{Pd} / \mathrm{C}$ (10 mol\%), in MeOH/THF (2:1) in a Parr shaker, which led to complete consumption of the starting material after $2 \mathrm{~h}$ and isolation of an intractable baseline material, the identity of which could not be resolved by NMR or IR spectroscopy, which showed the absence of a $v(C \equiv N)$ stretching frequency. Weak or absent $v(\mathrm{C} \equiv \mathrm{N})$ stretching frequencies can be an inherent feature of the compound structure, and their absence cannot be used to definitively aid a structure determination. ${ }^{17} \mathrm{~A}$ milder reductive approach was also attempted using $\mathrm{HCO}_{2} \mathrm{NH}_{4}$ (6 equiv), $\mathrm{Pd} / \mathrm{C}(10 \mathrm{~mol} \%)$ as the reductant, in $\mathrm{MeOH}$, at $65^{\circ} \mathrm{C}$, that led to a consumption of the starting material after $48 \mathrm{~h}$ and isolation of a complex mixture of products. ${ }^{18}$ The use of TMSI in MeCN, at ca. $82{ }^{\circ} \mathrm{C}$ also degraded the starting material, tentatively to acyclic sideproducts. ${ }^{19}$ Two oxidative debenzylation methods were also attempted, the first one using $\mathrm{KMnO}_{4}$ (10 equiv), $\mathrm{FeCl}_{3}$ (6 equiv), in acetone, at ca. $20{ }^{\circ} \mathrm{C}^{20}$ and the second using $\mathrm{CrO}_{3}$ (4 equiv), in $\mathrm{AcOH}$, at $20-80{ }^{\circ} \mathrm{C} .{ }^{21}$ Unfortunately, both methods failed, with the first giving only recovered starting material after $24 \mathrm{~h}$, while the second gave a complex mixture of products.

Nevertheless, two following deprotection methods gave limited success. Refluxing a neat TFA solution of pyrimidine 17 led to a consumption of the starting material after $2 \mathrm{~h}$, but gave a complex mixture of products that could not be purified by column chromatography (product was unstable 2D-TLC) or recrystallization. A similar result was observed with $\mathrm{BBr}_{3}$ (4 equiv), in $\mathrm{DCM}$, at $c a .-5{ }^{\circ} \mathrm{C}$ which led to a consumption of the starting material after $10 \mathrm{~min}$. NMR studies of the crude mixtures obtained from the above reactions tentatively revealed the presence of crude dihydroxypyrimidine 13. Therefore we attempted to telescope the last two steps of the conversion, and treated the crude product from each debenzylation with $\mathrm{PCl}_{5}\left(10\right.$ equiv) in $\mathrm{POCl}_{3}$, at $106{ }^{\circ} \mathrm{C}$, for $2 \mathrm{~h}$ (Scheme 6). This approach successfully gave the trichloropyrimidine 1, although in low yields (19 and 30\%, respectively).

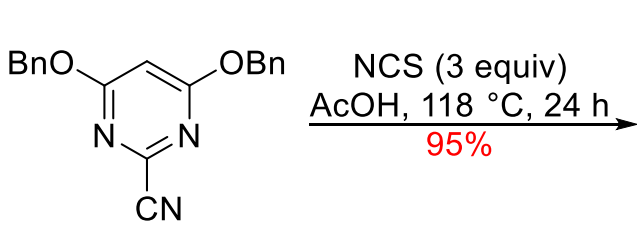

16

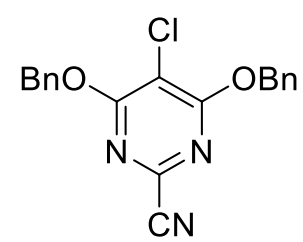

17
TFA, $72{ }^{\circ} \mathrm{C}, 2 \mathrm{~h}$ or

$\mathrm{BBr}_{3}(4 \mathrm{eq}), \mathrm{DCM},-5^{\circ} \mathrm{C}, 10 \mathrm{~min}$, then

$\underset{\mathrm{PCl}_{5}(10 \mathrm{eq}), \mathrm{POCl}_{3}, 106{ }^{\circ} \mathrm{C}, 2 \mathrm{~h}}{\stackrel{19}{\mathrm{and}} 30 \% \text { yield, respectively }}$<smiles>N#Cc1nc(Cl)c(Cl)c(Cl)n1</smiles>

1

Scheme 6. Preparation of the trichloropyrimidinecarbonitrile 1. 
Although this study has only yielded a small overall yield of the desired trichloropyrimidine 1, it has provided access to three new polyfunctionalized pyrimidines that can be of use in the further investigation of the chemistry and properties of pyrimidines. Efforts to improve the overall yield of the trichloropyrimidine 1 remain in progress.

\section{Conclusions}

4,6-Dichloro-2-(methylthio)pyrimidine (8) was converted into 4,6-bis(benzyloxy)-2-(methylthio)pyrimidine (14) by treatment with benzyl alcohol and $\mathrm{NaH}$. The latter was converted in two steps into 4,6-bis(benzyloxy)-2(methylsulfonyl)pyrimidine (15) and 4,6-bis(benzyloxy)pyrimidine-2-carbonitrile (16), respectively after oxidation to sulfone and displacement of the sulfone group with KCN. 4,6-Bis(benzyloxy)pyrimidine-2carbonitrile (16) was chlorinated with NCS to give 4,6-bis(benzyloxy)-5-chloropyrimidine-2-carbonitrile (17) in $95 \%$ yield and subsequently converted into 4,5,6-trichloropyrimidine-2-carbonitrile (1) in $30 \%$ yield over a two-step procedure.

\section{Experimental Section}

General. All chemicals were commercially available except those whose synthesis is described. Anhydrous $\mathrm{Na}_{2} \mathrm{SO}_{4}$ was used for drying organic extracts and all volatiles were removed under reduced pressure. Acetonitrile (MeCN), tetrahydrofuran (THF) and dichloromethane (DCM) were distilled over $\mathrm{CaH}_{2}$ before use. Reactions were protected from moisture with $\mathrm{CaCl}_{2}$ drying tubes or an Ar atmosphere. All reaction mixtures and column eluents were monitored by TLC using commercial glass backed thin layer chromatography (TLC) plates (Merck Kieselgel $60 \mathrm{~F}_{254}$ ). The plates were observed under UV light at 254 and $365 \mathrm{~nm}$. The technique of dry flash chromatography was used throughout for all non-TLC scale chromatographic separations using Merck Silica Gel 60 (less than $0.063 \mathrm{~mm}$ ). ${ }^{22}$ Melting points were determined using a PolyTherm-A, Wagner \& Munz, Koefler - Hotstage Microscope apparatus. Solvents used for recrystallization are indicated after the melting point. UV spectra were obtained using a Perkin-Elmer Lambda-25 UV/vis spectrophotometer and inflections are identified by the abbreviation "inf". IR spectra were recorded on a Shimadzu FTIR-NIR Prestige21 spectrometer with Pike Miracle Ge ATR accessory and strong, medium and weak peaks are represented by s, $\mathrm{m}$ and $\mathrm{w}$, respectively. ${ }^{1} \mathrm{H}$ and ${ }^{13} \mathrm{C}$ NMR spectra were recorded on a Bruker Avance 300 (at 300 and $75 \mathrm{MHz}$, respectively), or a 500 machine (at 500 and $125 \mathrm{MHz}$, respectively). Deuterated solvents were used for homonuclear lock and the signals are referenced to the deuterated solvent peaks. APT NMR studies were used for the assignment of the ${ }^{13} \mathrm{C}$ peaks as $\mathrm{CH}_{3}, \mathrm{CH}_{2}, \mathrm{CH}$, and $\mathrm{Cq}$ (quaternary). $\mathrm{APCl}^{+}$mass spectra were recorded on a Model 6110 Quadrupole MSD, Agilent Technologies. The elemental analysis was run by the London Metropolitan University Elemental Analysis Service. 4,6-Dichloro-2-(methylthio)pyrimidine (8) was prepared according to literature procedure. ${ }^{14}$

4,6-Bis(benzyloxy)-2-(methylthio)pyrimidine (14). To a stirred mixture of 4,6-dichloro-2(methylthio)pyrimidine (8) (195 mg, $1.00 \mathrm{mmol})$ in THF $(5 \mathrm{~mL})$ at ca. $20^{\circ} \mathrm{C}$ was added benzyl alcohol (270 mg, $2.50 \mathrm{mmol}$ ) followed by $\mathrm{NaH}(60 \%$ in oil, $88.0 \mathrm{mg}, 2.20 \mathrm{mmol})$. The mixture was protected with a $\mathrm{CaCl}_{2} \mathrm{drying}$ tube and stirred at $c a .50{ }^{\circ} \mathrm{C}$ until complete consumption of the starting material (TLC, $48 \mathrm{~h}$ ). DCM (10 mL) was then added, the mixture adsorbed onto silica and chromatography ( $n$-hexane/DCM 70:30) gave the title compound 14 ( $292 \mathrm{mg}, 86 \%$ ) as colorless plates, $\mathrm{mp} 48-49{ }^{\circ} \mathrm{C}$ (from $n$-pentane/-40 ${ }^{\circ} \mathrm{C}$ ); $\mathrm{R}_{f} 0.50$ ( $n$-hexane/DCM, 70:30); (found: $\mathrm{C}, 67.29 ; \mathrm{H}, 5.45 ; \mathrm{N}, 8.35 . \mathrm{C}_{19} \mathrm{H}_{18} \mathrm{~N}_{2} \mathrm{O}_{2} \mathrm{~S}$ requires $\left.\mathrm{C}, 67.43 ; \mathrm{H}, 5.36 ; \mathrm{N}, 8.28 \%\right) ; \lambda_{\max }(\mathrm{DCM}) / \mathrm{nm} 259$ 
$(\log \varepsilon 4.29) ; v_{\mathrm{max}} / \mathrm{cm}^{-1} 3092 \mathrm{w}, 3036 \mathrm{w}$ and 2926w (C-H), 1578s, 1551s, 1499w, 1422m, 1412m, 1364m, 1350w, 1317 w, 1277m, 1254m, 1204w, 1173s, 1105w, 1053m, 1030w, 962w, 949m, 907w, 901w, 839w, 824m, 754m, $729 \mathrm{~m} ; \delta_{\mathrm{H}}\left(500 \mathrm{MHz} ; \mathrm{CDCl}_{3}\right)$ 7.43-7.41 (4H, m, CH Ar), 7.39-7.36 (4H, m, CH Ar), 7.34-7.31 (2H, m, CH Ar), 5.84 $(1 \mathrm{H}, \mathrm{s}, \mathrm{CH} \mathrm{Ar}), 5.39\left(4 \mathrm{H}, \mathrm{s}, \mathrm{CH}_{2}\right), 2.54(3 \mathrm{H}, \mathrm{s}, \mathrm{SCH}) ; \delta_{\mathrm{C}}\left(125 \mathrm{MHz} ; \mathrm{CDCl}_{3}\right) 170.9(\mathrm{Cq}), 170.3(\mathrm{Cq}), 136.4(\mathrm{Cq}), 128.5$ $(\mathrm{CH}), 128.1(\mathrm{CH}), 128.0(\mathrm{CH}), 86.5(\mathrm{CH}), 68.4\left(\mathrm{CH}_{2}\right), 14.1\left(\mathrm{CH}_{3}\right) ; \mathrm{m} / z(\mathrm{APCl}+) 339\left(\mathrm{MH}^{+}, 100 \%\right), 279(34)$.

4,6-Bis(benzyloxy)-2-(methylsulfonyl)pyrimidine (15). To a stirred mixture of 4,6-bis(benzyloxy)-2(methylthio)pyrimidine (14) $(338 \mathrm{mg}, 1.00 \mathrm{mmol})$ in DCM (3 mL) cooled in an ice-bath to $\mathrm{ca} .0{ }^{\circ} \mathrm{C}$ was added in one portion $\mathrm{m}$-chloroperbenzoic acid $77 \%$ purity $(428 \mathrm{mg}, 2.00 \mathrm{mmol})$. The mixture was protected with a $\mathrm{CaCl}_{2}$ drying tube and stirred at ca. $20{ }^{\circ} \mathrm{C}$ until complete consumption of the starting material (TLC, $24 \mathrm{~h}$ ). Et ${ }_{2} \mathrm{O}(20$ $\mathrm{mL}$ ) and $\mathrm{Na}_{2} \mathrm{CO}_{3}$ sat. $(10 \mathrm{~mL}$ ) were then added, the two layers separated and the aqueous layer extracted with a further $10 \mathrm{~mL}$ of $\mathrm{Et}_{2} \mathrm{O}$. The combined organic phases were then dried over $\mathrm{Na}_{2} \mathrm{SO}_{4}$, filtered, adsorbed onto silica and chromatography ( $n$-hexane/DCM 20:80) gave the title compound 15 (348 mg, 94\%) as a colorless oil; $\mathrm{R}_{f} 0.36$ ( $n$-hexane/DCM 20:80); (found: $\mathrm{C}, 61.69 ; \mathrm{H}, 5.15 ; \mathrm{N}, 7.52 . \mathrm{C}_{19} \mathrm{H}_{18} \mathrm{~N}_{2} \mathrm{O}_{4} \mathrm{~S}$ requires C, 61.61; $\mathrm{H}, 4.90 ; \mathrm{N}$, $7.56 \%) ; \lambda_{\max }(\mathrm{DCM}) / \mathrm{nm} 245$ (log $\left.\varepsilon 3.65\right) ; v_{\max } / \mathrm{cm}^{-1} 3030 \mathrm{w}$ and 2926w (C-H), 1593s, 1530w, 1455m, 1439m, $1433 \mathrm{~m}, 1366 \mathrm{~m}, 1352 \mathrm{~m}, 1317 \mathrm{~m}, 1277 \mathrm{~m}, 1173 \mathrm{~s}, 1144 \mathrm{~s}, 1042 \mathrm{~m}, 1028 \mathrm{w}, 986 \mathrm{w}, 964 \mathrm{w}, 843 \mathrm{w}, 752 \mathrm{~m} ; \delta_{\mathrm{H}}(500 \mathrm{MHz} ;$ $\left.\mathrm{CDCl}_{3}\right) 7.44(4 \mathrm{H}, \mathrm{d}, \mathrm{J} 7.6, \mathrm{CH} \mathrm{Ar}), 7.40-7.33(6 \mathrm{H}, \mathrm{m}, \mathrm{CH} \mathrm{Ar}), 6.28(1 \mathrm{H}, \mathrm{s}, \mathrm{CH} \mathrm{Ar}), 5.47\left(4 \mathrm{H}, \mathrm{s}, \mathrm{CH}_{2}\right), 3.26(3 \mathrm{H}, \mathrm{s}$, $\left.\mathrm{SCH}_{3}\right) ; \delta_{\mathrm{C}}\left(125 \mathrm{MHz} ; \mathrm{CDCl}_{3}\right) 171.2(\mathrm{Cq}), 164.0(\mathrm{Cq}), 135.2(\mathrm{Cq}), 128.6(\mathrm{CH}), 128.5(\mathrm{CH}), 128.3(\mathrm{CH}), 93.9(\mathrm{CH}), 69.6$ $\left(\mathrm{CH}_{2}\right), 38.8\left(\mathrm{CH}_{3}\right) ; \mathrm{m} / z(\mathrm{APCl}+) 371\left(\mathrm{MH}^{+}, 100 \%\right), 124(51)$.

4,6-Bis(benzyloxy)pyrimidine-2-carbonitrile (16). To a stirred mixture of 4,6-bis(benzyloxy)-2(methylsulfonyl)pyrimidine (15) $\left(370 \mathrm{mg}, 1.00 \mathrm{mmol}\right.$ ) in $\mathrm{MeCN}(5 \mathrm{~mL})$ at ca. $20^{\circ} \mathrm{C}$ was added in one portion 18crown-6 (26 mg, $0.10 \mathrm{mmol})$ followed by $\mathrm{KCN}(195 \mathrm{mg}, 3.00 \mathrm{mmol})$. The mixture was protected with a $\mathrm{CaCl}_{2}$ drying tube and stirred at this temperature until complete consumption of the starting material (TLC, $24 \mathrm{~h}$ ). $\mathrm{Et}_{2} \mathrm{O}(20 \mathrm{~mL})$ and $\mathrm{H}_{2} \mathrm{O}(10 \mathrm{~mL})$ were then added, the two layers were separated and the aqueous layer was extracted with a further $10 \mathrm{~mL}$ of $\mathrm{Et}_{2} \mathrm{O}$. The combined organic phases were then dried over $\mathrm{Na}_{2} \mathrm{SO}_{4}$, filtered and the mixture adsorbed onto silica and chromatography ( $n$-hexane/DCM 70:30) gave the title compound 16 (277 mg, 87\%) as colorless plates, $\mathrm{mp} 59-60{ }^{\circ} \mathrm{C}$ (from $n$-hexane/-40 ${ }^{\circ} \mathrm{C}$ ); $\mathrm{R}_{f} 0.17$ ( $n$-hexane/DCM 70:30); (found: C, 72.02; $\mathrm{H}, 4.86 ; \mathrm{N}, 13.25 . \mathrm{C}_{19} \mathrm{H}_{15} \mathrm{~N}_{3} \mathrm{O}_{2}$ requires $\left.\mathrm{C}, 71.91 ; \mathrm{H}, 4.76 ; \mathrm{N}, 13.24 \%\right) ; \lambda_{\max }(\mathrm{DCM}) / \mathrm{nm} 256$ (log $\left.\varepsilon 3.69\right)$; $v_{\text {max }} / \mathrm{cm}^{-1} 3034 \mathrm{w}$ and $2957 \mathrm{w}(\mathrm{C}-\mathrm{H}), 1591 \mathrm{~s}, 1535 \mathrm{w}, 1530 \mathrm{w}, 1454 \mathrm{w}, 1427 \mathrm{~m}, 1366 \mathrm{~m}, 1348 \mathrm{~m}, 1285 \mathrm{~m}, 1209 \mathrm{w}$, $1173 \mathrm{~s}, 1045 \mathrm{~m}, 1028 \mathrm{~m}, 984 \mathrm{~m}, 899 \mathrm{w}, 841 \mathrm{~m}, 750 \mathrm{~m}, 737 \mathrm{~m} ; \delta_{\mathrm{H}}\left(500 \mathrm{MHz} ; \mathrm{CDCl}_{3}\right) 7.45-7.43(4 \mathrm{H}, \mathrm{m}, \mathrm{CH} \mathrm{Ar}), 7.41-$ $7.34(6 \mathrm{H}, \mathrm{m}, \mathrm{CH} \mathrm{Ar}), 6.29(1 \mathrm{H}, \mathrm{s}, \mathrm{CH} \mathrm{Ar}), 5.42\left(4 \mathrm{H}, \mathrm{s}, \mathrm{CH}_{2}\right) ; \delta_{\mathrm{C}}\left(125 \mathrm{MHz} ; \mathrm{CDCl}_{3}\right) 170.7(\mathrm{Cq}), 142.3(\mathrm{Cq}), 135.3(\mathrm{Cq})$, $128.6(\mathrm{CH}), 128.5(\mathrm{CH}), 128.4(\mathrm{CH}), 115.5(\mathrm{Cq}), 95.0(\mathrm{CH}), 69.4\left(\mathrm{CH}_{2}\right) ; \mathrm{m} / z$ (MALDI-TOF) $118\left(\mathrm{MH}^{+}, 18 \%\right), 317$ $\left(\mathrm{M}^{+}, 100\right), 313(56)$.

4,6-Bis(benzyloxy)-5-chloropyrimidine-2-carbonitrile (17). To a stirred mixture of 4,6bis(benzyloxy)pyrimidine-2-carbonitrile (16) $(317 \mathrm{mg}, 1.00 \mathrm{mmol})$ in $\mathrm{AcOH}(5 \mathrm{~mL})$ at $\mathrm{ca} .20^{\circ} \mathrm{C}$ was added in one portion $\mathrm{N}$-chlorosuccinimide $\left(401 \mathrm{mg}, 3.00 \mathrm{mmol}\right.$ ). The mixture was protected with a $\mathrm{CaCl}_{2}$ drying tube and stirred at ca. $118{ }^{\circ} \mathrm{C}$ until complete consumption of the starting material (TLC, $24 \mathrm{~h}$ ). Et ${ }_{2} \mathrm{O}(20 \mathrm{~mL})$ and a saturated solution of $\mathrm{NaHCO}_{3}(10 \mathrm{~mL})$ were then added, the two layers separated and the aqueous layer extracted with a further $10 \mathrm{~mL}$ of $\mathrm{Et}_{2} \mathrm{O}$. The combined organic phases were then dried over $\mathrm{Na}_{2} \mathrm{SO}_{4}$, filtered and the mixture adsorbed onto silica and chromatography ( $n$-hexane/DCM 70:30) gave the title compound 17 (334 mg, 95\%) as colorless plates, $\mathrm{mp} 67-68^{\circ} \mathrm{C}$ (from $n$-hexane/-40 ${ }^{\circ} \mathrm{C}$ ); $\mathrm{R}_{f} 0.21$ ( $n$-hexane/DCM, 70:30); (found: $\mathrm{C}, 65.13 ; \mathrm{H}, 3.93 ; \mathrm{N}, 12.05 . \mathrm{C}_{19} \mathrm{H}_{14} \mathrm{ClN}_{3} \mathrm{O}_{2}$ requires $\left.\mathrm{C}, 64.87 ; \mathrm{H}, 4.01 ; \mathrm{N}, 11.94 \%\right) ; \lambda_{\max }(\mathrm{DCM}) / \mathrm{nm} 267$ (log $\left.\varepsilon 3.72\right)$, $279 \inf (3.70) ; v_{\max } / \mathrm{cm}^{-1} 3038 \mathrm{w}, 2957 \mathrm{w}, 2922 \mathrm{w}$ and $2853 \mathrm{w}(\mathrm{C}-\mathrm{H}), 1584 \mathrm{w}, 1566 \mathrm{~s}, 1499 \mathrm{w}, 1443 \mathrm{w}, 1406 \mathrm{~m}$, 1348s, 1312w, 1290w, 1124s, 1082w, 1030w, 1024w, 1016w, 986w, 941w, 906m, 777m, 752w, 737s, 723m; $\delta_{\mathrm{H}}\left(500 \mathrm{MHz} ; \mathrm{CDCl}_{3}\right) 7.47(4 \mathrm{H}, \mathrm{d}, J$ 7.0, $\mathrm{CH} \mathrm{Ar}), 7.42-7.34(6 \mathrm{H}, \mathrm{m}, \mathrm{CH} \mathrm{Ar}), 5.51\left(4 \mathrm{H}, \mathrm{s}, \mathrm{CH}_{2}\right) ; \delta_{\mathrm{C}}\left(125 \mathrm{MHz}^{\mathrm{C}} \mathrm{CDCl}_{3}\right)$ 
$165.6(\mathrm{Cq}), 138.2(\mathrm{Cq}), 134.9(\mathrm{Cq}), 128.7(\mathrm{CH}), 128.6(\mathrm{CH}), 128.2(\mathrm{CH}), 115.1(\mathrm{Cq}), 104.9(\mathrm{Cq}), 70.4\left(\mathrm{CH}_{2}\right) ; \mathrm{m} / \mathrm{z}$ $(\mathrm{APCl}+) 354\left(\mathrm{MH}^{+}+2,33 \%\right), 353\left(\mathrm{M}^{+}+2,25\right), 352\left(\mathrm{MH}^{+}, 100\right)$.

\section{Syntheses of 4,5,6-trichloropyrimidine-2-carbonitrile (1)}

(a) By reaction with trifluoroacetic acid. A stirred mixture of 4,6-bis(benzyloxy)-5-chloropyrimidine-2carbonitrile (17) $(70.4 \mathrm{mg}, 0.200 \mathrm{mmol})$ in TFA $(2 \mathrm{~mL})$ was stirred at ca. $72{ }^{\circ} \mathrm{C}$ until complete consumption of the starting material (TLC, $2 \mathrm{~h}$ ). The solvent was then evaporated under vacuo and to the crude product was added $\mathrm{PCl}_{5}(416 \mathrm{mg}, 2.00 \mathrm{mmol})$ and $\mathrm{POCl}_{3}(2 \mathrm{~mL})$ and the mixture stirred at ca. $106{ }^{\circ} \mathrm{C}$ until complete consumption of the starting material (TLC, $2 \mathrm{~h}) . \mathrm{Et}_{2} \mathrm{O}(20 \mathrm{~mL})$ and $\mathrm{H}_{2} \mathrm{O}(10 \mathrm{~mL})$ were then added, the two layers separated and the aqueous layer extracted with a further $10 \mathrm{~mL}$ of $\mathrm{Et}_{2} \mathrm{O}$. The combined organic phases were then dried over $\mathrm{Na}_{2} \mathrm{SO}_{4}$, filtered and the mixture adsorbed onto silica and chromatography ( $n$-hexane/DCM 60:40) gave 4,5,6-trichloropyrimidine-2-carbonitrile (1) $(8.0 \mathrm{mg}, 19 \%)$ as colorless needles, $\mathrm{mp} 62-63{ }^{\circ} \mathrm{C}$ (from sublimation at $40{ }^{\circ} \mathrm{C}, 20$ mbar, lit. ${ }^{13} 62-63^{\circ} \mathrm{C}$ ); $\mathrm{R}_{f} 0.81$ ( $n$-hexane/DCM, 60:40); $v_{\max } / \mathrm{cm}^{-1} 2268 \mathrm{w}$ (CN), $1529 \mathrm{w}$, $1497 \mathrm{~s}, 1464 \mathrm{w}, 1350 \mathrm{~s}, 1337 \mathrm{w}, 1315 \mathrm{~m}, 1300 \mathrm{~m}, 1275 \mathrm{~m}, 1256 \mathrm{~m}, 1065 \mathrm{~m}, 1057 \mathrm{~m}, 910 \mathrm{~m}, 831 \mathrm{~m}, 818 \mathrm{~m}, 770 \mathrm{~m}$; $\delta_{\mathrm{C}}\left(125 \mathrm{MHz} ; \mathrm{CDCl}_{3}\right) 161.1(\mathrm{~s}), 139.7(\mathrm{~s}), 133.2(\mathrm{~s}), 113.4(\mathrm{~s})$, identical to an authentic sample. ${ }^{13}$

(b) By reaction with boron tribromide. To a stirred mixture of 4,6-bis(benzyloxy)-5-chloropyrimidine-2carbonitrile (17) $(70.4 \mathrm{mg}, 0.200 \mathrm{mmol})$ in DCM $(8 \mathrm{~mL})$, at ca. $-5{ }^{\circ} \mathrm{C}$ was added $\mathrm{BBr}_{3}(1 \mathrm{M}$ in DCM, $0.8 \mathrm{~mL}, 0.8$ $\mathrm{mmol}$ ) and the mixture was stirred at this temperature until complete consumption of the starting material (TLC, $10 \mathrm{~min}$ ). The precipitate was then filtered, washed with DCM $(5 \mathrm{~mL})$ and dried over air. The crude solid was then transferred quantitatively to a round bottom flask to which was added $\mathrm{PCl}_{5}(416 \mathrm{mg}, 2.00 \mathrm{mmol})$ and $\mathrm{POCl}_{3}(2 \mathrm{~mL})$ and the mixture stirred at ca. $106^{\circ} \mathrm{C}$ until complete consumption of the starting material (TLC, 2 h). $\mathrm{Et}_{2} \mathrm{O}(20 \mathrm{~mL})$ and $\mathrm{H}_{2} \mathrm{O}(10 \mathrm{~mL})$ were then added, the two layers were separated and the aqueous layer was extracted with a further $10 \mathrm{~mL}$ of $\mathrm{Et}_{2} \mathrm{O}$. The combined organic phases were then dried over $\mathrm{Na}_{2} \mathrm{SO}_{4}$, filtered and the mixture adsorbed onto silica and chromatography ( $n$-hexane/DCM 60:40) gave 4,5,6trichloropyrimidine-2-carbonitrile (1) $(12.5 \mathrm{mg}, 30 \%)$, identical to that reported above.

\section{Acknowledgements}

The authors thank I. J. Stavrou and C. P. Kapnissi-Christodoulou for APCl+ mass spectra, the Cyprus Research Promotion Foundation (Grants: ETPATHII/0308/06, NEKYP/0308/02 YГEIA/0506/19 and ENIIX/0308/83) and the following organizations and companies in Cyprus for generous donations of chemicals and glassware: the State General Laboratory, the Agricultural Research Institute, the Ministry of Agriculture, MedoChemie Ltd, Medisell Ltd and Biotronics Ltd. Furthermore, we thank the A. G. Leventis Foundation for helping to establish the NMR facility at the University of Cyprus.

\section{Supplementary Material}

${ }^{1} \mathrm{H}$ and ${ }^{13} \mathrm{C}$ NMR spectra for all new compounds are available in the supplementary file accompanying this paper.

\section{References}

1. Brown, D. J. Pyrimidines and their Benzo Derivatives. In Comprehensive Heterocyclic Chemistry; Boulton, A. J.; McKillop, A., Ed.; Katritzky, A. R.; Rees, C. W., Eds.; Pergamon Press: Oxford, UK, 1984; Vol. 3, Chapter 2.13; pp. 57-155. 
2. Ukrainets, I. V.; Tugaibei, I. A.; Bereznykova, N. L.; Karvechenko, V. N.; Turov, A. V. Chem. Heterocycl. Com. 2008, 44, 565-575.

https://doi.org/10.1007/s10593-008-0076-7

3. Amr, A. E., Nermien, M. S., Abdulla, M. M. Monatsh. Chem. 2007, 138, 699-707.

https://doi.org/10.1007/s00706-007-0651-0

4. Gorlitzer, K., Herbig, S., Walter, R.D. Pharmazie 1997, 52, 670-672.

5. Wagner, E., Al-Kadasi, K., Zimecki, M., Sawka-Dobrowolska, W. Eur. J. Med. Chem. 2008, 43, 2498-2504. https://doi.org/10.1016/i.ejmech.2008.01.035

6. Koutentis, P. A.; Rees, C. W. J. Chem. Soc., Perkin Trans. 1, 2000, 1089-1094.

https://doi.org/10.1039/B000209G

7. Kalogirou, A. S.; Manoli, M.; Koutentis, P. A. Tetrahedron Lett. 2017, 58, 2618-2621. https://doi.org/10.1016/j.tetlet.2017.05.082

8. Kalogirou, A. S.; Koutentis, P. A. Molbank 2019, 2019, M1084. https://doi.org/10.3390/M1084

9. Kalogirou, A. S.; Manoli, M.; Koutentis, P. A. Tetrahedron Lett. 2018, 59, 3589-3593. https://doi.org/10.1016/j.tetlet.2018.08.007

10. Andrew, H. F.; Poole, V. D. US Pat. 3,120,507, 1964.

11. Treves, G. R. US Pat. 4,092,150, 1978.

12. Narr, B.; Roch, J.; Müller, E.; Haarmann, W. US Pat. 3,975,384, 1976.

13. Perreault, S.; Chandrasekhar, J.; Cui, Z.-H.; Evarts, J.; Hao, J.; Kaplan, J. A.; Kashishian, A.; Keegan, K. S.; Kenney, T.; Koditek, D.; Lad, L.; Lepist, E.-I.; McGrath, M. E.; Patel, L.; Phillips, B.; Therrien, J.; Treiberg, J.; Yahiaoui, A.; Phillips, G. J. Med. Chem. 2017, 60, 1555-1567. https://doi.org/10.1021/acs.jmedchem.6b01821

14. Raboisson, P.; Belfrage, A.; Classon, B.; Lindquist, K.; Nilsson, K.; Rosenquist, A.; Samuelson, B.; Wahling, H. WO2008/095999A1, 2008.

15. Kalogirou, A. S.; Koutentis, P. A. Molbank 2019, 2019, M1086. https://doi.org/10.3390/M1086

16. Chen, X.; Duzheng, W.; Jianxin, X.; Chuanmin, W.; Xiaobin, Z. CN106008368, 2016.

17. Bellamy, L. J. In The Infrared Frequencies of Complex Molecules; Chapman and Hall, London, U.K., 1975, Chapter 15, pp 294-298.

https://doi.org/10.1007/978-94-011-6017-9

18. Antonios-Mccrea, W. R.; Barsanti, P. A.; Hu, C.; Jin, X.; Lin, X.; Martin, E. J.; Pan, Y.; Pfister, K. B.; Renhowe, P. A.; Sendzik, M.; Sutton, J.; Wan, L. WO2012/101065, 2012.

19. Goudgaon, N. M.; Naguib, F. N. M.; el Kouni, M. H.; Schinazi, R. F. J. Med. Chem. 1993, 36, 4250-4254.

20. Lai, S.; Lee, D. G. Tetrahedron 2002, 58, 9879-9887.

https://doi.org/10.1016/S0040-4020(02)01227-9

21. Angyal, S. J.; James, K. Carbohydr. Res. 1970, 12, 147-149.

https://doi.org/10.1016/S0008-6215(00)80237-2

22. Harwood, L. M. Aldrichimica Acta 1985, 18, 25-25. 